\title{
Guidelines to integrate spirituality and spiritual care in occupational therapy education: A modified Delphi study
}

Thuli G. Mthembu, Lisa Wegner \& Nicolette V. Roman

\begin{abstract}
This modified Delphi study aimed to develop educational guidelines for integrating spirituality and spiritual care into occupational therapy education. The first round comprised a self-administered questionnaire, the second round used a faceto-face workshop, and last round reviewed the developed educational guidelines, which reached the highest agreement and median values greater than 3.25. A panel of 18 comprised occupational therapy educators, clinicians, and nursing experts were recruited. A total of 126 out of 142 items reached the highest agreements from the panel participants, categorized based on the content knowledge-based, importance, skills, ethics, pedagogical approaches, teaching and learning strategies, and assessment of student learning.
\end{abstract}

\section{Keywords}

Education; modified Delphi; occupational therapy; spiritual care; spirituality

\section{Introduction}

There has been an ongoing debate regarding the integration of spirituality and spiritual care in occupational therapy. In making such an integration more effective and significant, there is a need for guidelines that might be used to embed spirituality and spiritual care into occupational therapy education (Johnston \& Mayers, 2005; Jones, 2016; Mthembu, Wegner, \& Roman, 2017a). Occupational therapy educators, students, and clinicians increasingly work in culturally, spiritually, and religiously diverse societies. Therefore, there is a need for these professionals to frequently acknowledge spirituality as an essential aspect of a person, influenced by the environment, and often providing meaning and purpose through occupations (Egan \& Swedersky, 2003; Polatjako, Townsend, \& Craik, 2007; Sumsion, Tischler-Draper, \& Heinicke, 2011). Spirituality is further identified as an essential component of the integrative care of people, groups, and communities in some occupational therapy models. According to the World Health Organization (2015) and Moreira-Almeida, Sharma, Janse van Rensburg, Verhagen, and Cook (2016), spirituality is considered an important determinant of health, quality of life, and well-being. According to Puchalski, Vitillo, Hull, and Reller (2014), spirituality is defined as: 
a dynamic and intrinsic aspect of humanity through which persons seek ultimate meaning, purpose, and transcendence, and experience relationship to self, family, others, community, society, nature, and the significant or sacred. Spirituality is expressed through beliefs, values, traditions and practices. (p. 646)

Spiritual care means attending to the whole person, including physical, emotional, social, and spiritual dimensions of one's experience (Puchalski, 2001). These dimensions seem to be related to person-centered and holistic approaches, which are fundamental to occupational therapy practice and education. Educators, students, and clinicians reported, however, not being adequately prepared for the integration of spirituality and spiritual care in occupational therapy education (Jones, 2016; Mthembu et al., 2017a; Thompson \& MacNeil, 2006). Additionally, educators, students, and clinicians are faced with the challenge of integrating spirituality and spiritual care when faced with time constraints (Mthembu et al., 2017a). There is increasing awareness of the significant role of spirituality and spiritual care in the occupational therapy profession (Brémault-Phillips et al., 2015; Hemphill, 2015; Kirsh, Dawson, Antolikova, \& Reynolds, 2001; Morris et al., 2014). A mixed-methods study by Morris and colleagues (2014) found that there was a gap among theory, education, and practice regarding the integration of spirituality in occupational therapy. These findings corroborate systematic reviews that highlighted a limited base of evidence on guidelines to integrate spirituality and spiritual care into health sciences education (Bennett \& Thompson, 2015; Mthembu, Wegner, \& Roman, 2016).

Previous studies on guidelines for integrating spirituality and spiritual care into professional education have been developed in a number of health care professions including counselling (Henriksen, Polonyi, Bornsheuer-Boswell, Greger, \& Watts, 2015), medicine (Janse van Rensburg, 2014), and social work (Bhagwan, 2002). For the occupational therapy profession, however, there are few guidelines that may be used to integrate spirituality and spiritual care in education (Hoyland \& Mayers, 2005; Johnston \& Mayers, 2005). This is further supported by the systematic review conducted by Mthembu, Wegner, and Roman (2016), which found that there were no studies seeking consensus about guidelines to incorporate spirituality and spiritual care into occupational therapy education. Hence, more research is needed to design and develop guidelines that may reflect how to prepare occupational therapy educators and students for spiritually sensitive education and practice. Additionally, such an approach may assist in bridging the gap in theory, practice, and research regarding spirituality and spiritual care in occupational therapy education. Therefore, this study aimed to design and develop guidelines for integrating spirituality and spiritual care in occupational therapy education.

\section{Methodology}

\section{Design}

A three-round modified Delphi method was used to design and develop guidelines for integrating spirituality and spiritual care into occupational therapy education. Modified Delphi method refers to the combination of a "self-administered questionnaire and a physical meeting of the experts to discuss the results or rate the indicators" (Boulkedid, Abdoul, Loustau, Sibony, \& Albert, 2011, p. 2). The modified Delphi method allows the 
use of questionnaire-based rounds and the physical meeting, which is considered as a round (Boulkedid et al., 2011; Custer, Scarcella, \& Stewart, 1999). Likewise, another benefit of using the modified Delphi technique is that previous work forms the foundation of the study (Custer et al., 1999). In the current study, the modified Delphi method consisted of a first round of a questionnaire used for survey, face-to-face workshop as a second round, and a third round where items that reached highest agreements were reviewed. The selfadministered questionnaire study had a combination of qualitative and quantitative data, which assisted to gain consensus (Hasson, Keeney, \& McKenna, 2000). On contrary, the face-to-face workshop was used as part of the modified Delphi technique, which is consistent with the Estimate-Talk-Estimate process, where panelists can interact about the rated items and provide reasons and justifications (Armstrong, 2001; Green, Armstrong, \& Graefe, 2007; Khosrow-Pour, 2015). The Estimate-Talk-Estimate process was used to help the panellists discuss the guidelines and reach consensus (Eubank et al., 2016). Moreover, the method Delphi method used an iterative process designed to combine expert opinion into group consensus about the constructs of spirituality and spiritual care in occupational therapy education (Hasson et al., 2000; Keenay, Hasson, \& Mckenna, 2006; Skulmoski, Hartman, \& Krahn, 2007). The process was stopped once consensus was reached, which indicated that theoretical saturation was achieved (Skulmoski et al., 2007). This study received ethical approval from the Research Ethics Committee at the University of the Western Cape (ethical clearance number 14/4/18). All participants gave informed consent, and were informed about their right to withdraw from the study without repercussion. Boulkedid and colleagues (2011) listed five quality indicators that might be used as part of the practical guidance on how to improve the optimal use and reporting of Delphi method. These quality indicators are questionnaire for the first round, experts, sending questionnaire, next rounds, and final round. In the current modified Delphi method, the research team used the suggested quality indicators as incorporated in the following sections.

\section{Participant selection}

Selection of the experts is one of the quality indicators suggested by Boulkedid and colleagues (2011). It highlights the importance of asking potential panel participants about their willingness to participate in the modified Delphi (Boulkedid et al., 2011). A list of the participants was compiled with their contact details and they were invited to be part of the study in April 2016. Therefore, a purposive sampling was used to recruit 40 eligible participants who were furnished with an information sheet explaining the procedure of the modified Delphi and the benefits from participation. The participants were contacted via an email, which forms part of the quality indicator of sending the questionnaire. Only 11 participants agreed to be part of the current study's first round. These participants were geographically diverse and included international and national experts in the following disciplines: occupational therapy educators $(\mathrm{n}=6)$, occupational therapists $(\mathrm{n}=3)$, nursing $(n=2)$. The inclusion criteria were set as participants: (a) with expertise in the field of health sciences education, spirituality, and spiritual care; (b) qualified with a bachelor's degree and holding a senior position in education or health; (c) conducted research and published about spirituality and spiritual care; and (d) employed as educators and clinicians in either universities, private practice, public health services, or schools. 
For the second round, there were eight panel participants who were occupational therapy educators $(n=3)$, occupational therapy clinical fieldwork coordinators $(n=2)$, a community fieldwork supervisor/educator $(\mathrm{n}=1)$, a teaching specialist $(\mathrm{n}=1)$, and an interdisciplinary professional education specialist $(n=1)$. Some of the panel participants participated in the first round were invited to be part of the second-round face-to-face workshop.

\section{Data collection}

Self-administered questionnaire is another quality indicator that Boulkedid and colleagues (2011) suggested as an effective measurement to be used for data collection in a modified Delphi technique. In the present study, a self-administered questionnaire with parts A and B was used to collect data. Part A elicited the participants' demographic information, country, education level, place of employment, and nature of employment. Part B consisted of 142 items, which were developed from the preceding previous studies conducted by the research team (TGM, LW, and NVR). These items were of importance for integrating spirituality and spiritual care into occupational therapy education. In addition, the items were rated using a 4-point Likert scale ( 1 = strongly disagree; $2=$ disagree; $3=$ agree; $4=$ strongly agree) to test for consensus among participants of the study. The 4-point Likert scale is useful because it tends to give a more positive response to questions as suggested by Garland (1991).

The research team used Google as a platform for creating the self-administered questionnaire and disseminating it to the participants. Additionally, the Google platform automatically saved the participants' responses into an excel spreadsheet form. The data collection was conducted in two rounds between March and September 2016, but the third round was used as a review of the rated items for the guidelines.

Round 1 consisted of a survey conducted using self-administered questionnaire, which was designed based on the findings from preliminary studies produced from the systematic review, and used quantitative and exploratory-descriptive qualitative methods. This is consistent with Custer and colleagues (1999), who highlight that the first round of the modified Delphi begins with panelists being offered a set of items heretofore determined. The findings of the previous studies were collated using a matrix framework by the research team prior to the modified Delphi study. The research team constructed 142 items from the previous studies preceding this study, which were important for spirituality and spiritual care in occupational therapy education. The following categories were developed from preliminary studies related to the modified Delphi study. These categories are: (1) knowledge-base for spirituality and spiritual care; (2) importance of spirituality and spiritual care; (3) skills required for spirituality and spiritual care; (4) spirituality and spiritual care in occupational therapy related to ethics of care; (5) pedagogical approaches for spirituality and spiritual care; (6) teaching and learning strategies for spirituality and spiritual care; and (7) assessment strategies for spirituality and spiritual care. Then, the self-administered questionnaire for the first round was sent to the participants via an email as a link, or word document for those who had poor access to internet. The panel participants were asked to rate and comment on the items. 
For Round 2, the results of Round 1 were subsequently used to prepare a presentation for the face-to-face workshop, which allowed the panel participants to make further clarifications on the items that reached an agreement. The second round presents the modification of Delphi method, which is consistent with Custer and colleagues (1999), Armstrong (2001), and Avella (2016), who indicated panel participants can be given the opportunity to discuss the items to the point that they are able to agree with each other. A goal of the face-to-face workshop was to discover the reasons, clarifications, and justifications regarding the items rated in Round 1 in preparation for integration of spirituality and spiritual care into occupational therapy education. A second goal was to discuss the development of possible guidelines that might be used to facilitate the integration of spirituality and spiritual care. During the face-to-face workshop, the panel participants made comments, which were incorporated into the guidelines. The comments from the panel participants contributed to the understanding of spirituality, particularly when contextualized within an African perspective. Overall, the second round supported the Estimate-Talk-Estimate process, whereby the panel participants were able to interact about the items and justified their consensus (Green et al., 2007; Khosrow-Pour, 2015). The majority of the items were rated high in Rounds 1 and 2, this resulted to the compilation of guidelines, which were sent to the panel participants for review in the subsequent round. This supports Keenay and colleagues (2006) that number of rounds depends on time available and exhaustion occurred after two rounds as experts tend to be busy.

Round 3 comprised validation of the rated guidelines as true reflections of what the panel participants agreed on in Rounds 1 and 2. The panel participants were asked to check the correctness of the responses related to their agreement about the guidelines that should be used to integrate spirituality and spiritual care into occupational therapy education as part of the final round.

\section{Data analysis}

In this study, descriptive statistical analysis was computed using the Statistical Package for the Social Sciences (SPSS) software 23 (2016). The research team checked the completeness and correctness of the responses on the items of the questionnaire. The descriptive statistics included participants' characteristics using numbers (n) and percentages (\%). Hsu and Sandford (2007) and Boulkedid and colleagues (2011) recommended that at least 70\% of panel participants need to rate 3 or higher on a 4-point Likert type scale, and the median score has to be greater than 3.25. For each item, from part B of the self-administered questionnaire survey, the median scores as a measure of central tendency together with percentile range were used as indicators to determine the level of agreement and the degree of importance among panel participants, as these indices are mostly used in health research (Hasson et al., 2000). 


\section{Results}

For Round 1, of the recruited 40 panel participants, 11 agreed to be part of the modified Delphi study, completed, and returned the questionnaire, giving a 27.5\% response rate. The age of the participants ranged from 32 to 67 years with a mean and standard deviation of $45.63 \pm 10.67$. The majority of the participants $(72 \%)$ indicated that they were from South Africa, followed by the Netherlands (9\%), and the United Kingdom (9\%). One participant (9\%) did not indicate country of origin. Less than half $(45.5 \%)$ of the participants were employed as occupational therapy full-time academics in institutions of higher learning, while some were clinicians in departments of education or health, or in private practice. In addition, there were participants who reported that they were postgraduate supervisors, researchers at the knowledge center of spirituality and health care, doctoral students, and part-time academics. The results section summarizes the modified Delphi in terms of consensus based on the agreement percentages, median, and interquartile range as presented in the Tables 1-7. 
Table 1. Knowledge-base for spirituality and spiritual care.

\begin{tabular}{|c|c|c|c|}
\hline & $\begin{array}{c}\text { Consensus } \\
(\%)\end{array}$ & Median & $\begin{array}{l}\text { Interquartile } \\
\text { range }\end{array}$ \\
\hline $\begin{array}{l}\text { 1. To have an understanding of the following concept and provide } \\
\text { analysis: spirituality }\end{array}$ & 90.9 & 4 & $3-4$ \\
\hline $\begin{array}{l}\text { 2. To have an understanding of the following concept and provide } \\
\text { analysis: spiritual care }\end{array}$ & 63.6 & 4 & $3-4$ \\
\hline $\begin{array}{l}\text { 3. To have an understanding of the following concepts and provide } \\
\text { analysis: religion }\end{array}$ & 54.5 & 4 & $4-4$ \\
\hline $\begin{array}{l}\text { 4. To have an understanding of the following concepts and provide } \\
\text { analysis: spiritual well-being }\end{array}$ & 81.8 & 4 & $4-4$ \\
\hline $\begin{array}{l}\text { 5. To have an understanding of the following concepts and provide } \\
\text { analysis: spiritual coping }\end{array}$ & 63.6 & 4 & $3-4$ \\
\hline $\begin{array}{l}\text { 6. To have an understanding of the following concepts and provide } \\
\text { analysis: spiritual distress }\end{array}$ & 63.6 & 4 & $3-4$ \\
\hline $\begin{array}{l}\text { 7. To have an understanding of the following concepts and provide } \\
\text { analysis: spiritual needs }\end{array}$ & 81.8 & 4 & $3-4$ \\
\hline $\begin{array}{l}\text { 8. To have an understanding of the following concepts and provide } \\
\text { analysis: spiritual diversity }\end{array}$ & 90.9 & 4 & $4-4$ \\
\hline $\begin{array}{l}\text { 9. To demonstrate an integrated approach to address spirituality and } \\
\text { spiritual care by considering moral and faith development-related } \\
\text { issues, bio-psycho-social-spiritual journeys and critical view of } \\
\text { individuals }\end{array}$ & 63.6 & 4 & $3-4$ \\
\hline $\begin{array}{l}\text { 10. To be introduced to theories of stress and coping in order to help } \\
\text { them to understand humans as a whole }\end{array}$ & 72.7 & 4 & $3-4$ \\
\hline $\begin{array}{l}\text { 11. To engage in theory of journaling with students through } \\
\text { maturation which also enhances students' awareness of the } \\
\text { essence of spirituality }\end{array}$ & 45.5 & 3.5 & $2.75-4$ \\
\hline $\begin{array}{l}\text { 12. To be aware of how to incorporate spirituality in all aspects of } \\
\text { occupational therapy }\end{array}$ & 45.5 & 4 & $3-4$ \\
\hline 13. To be introduced to spirituality in first year & 72.7 & 4 & $3-4$ \\
\hline 14. To consider spirituality in order to improve clients quality of life & 72.7 & 4 & $3-4$ \\
\hline 15. To consider clients' spirituality and religious beliefs & 72.7 & 4 & $3-4$ \\
\hline $\begin{array}{l}\text { 16. To introduce students to occupational injustices and their } \\
\text { relationship to spirituality }\end{array}$ & 54.5 & 4 & $3-4$ \\
\hline $\begin{array}{l}\text { 17. To introduce students to a theory of meaning of occupational } \\
\text { engagement and spirituality }\end{array}$ & 63.6 & 4 & $3-4$ \\
\hline $\begin{array}{l}\text { 18. To explain to students about spirituality so that students would be } \\
\text { able to consider it in fieldwork }\end{array}$ & 63.6 & 4 & $3.5-4$ \\
\hline $\begin{array}{l}\text { 19. To have an understanding of the differences between spirituality } \\
\text { and religion }\end{array}$ & 72.7 & 4 & $3-4$ \\
\hline 20. To know how spirituality and religion are both connected & 45.5 & 4 & $3-4$ \\
\hline $\begin{array}{l}\text { 21. To be aware of the guidelines and use them to include spirituality } \\
\text { in teaching and learning }\end{array}$ & 54.5 & 4 & $3.25-4$ \\
\hline $\begin{array}{l}\text { 22. To be able to address fears of addressing spirituality in teaching and } \\
\text { learning }\end{array}$ & 81.8 & 4 & $4-4$ \\
\hline $\begin{array}{l}\text { 23. To know how to tackle the topic in the classroom without being } \\
\text { emotional and sensitive }\end{array}$ & 63.6 & 4 & $3.5-4$ \\
\hline
\end{tabular}


Table 2. Importance of spirituality and spiritual care.

\begin{tabular}{|c|c|c|c|}
\hline & $\begin{array}{c}\text { Consensus } \\
(\%)\end{array}$ & Median & $\begin{array}{l}\text { Interquartile } \\
\text { range }\end{array}$ \\
\hline $\begin{array}{l}\text { 1. To be aware of the importance of spirituality in different fieldwork } \\
\text { placements }\end{array}$ & 63.6 & 4 & $3.5-4$ \\
\hline $\begin{array}{l}\text { 2. To be aware that spirituality Improves well-being and health of the } \\
\text { client }\end{array}$ & 72.7 & 4 & $4-4$ \\
\hline 3. To be aware how to Include spirituality in Individual process & 54.5 & 4 & $2.5-4$ \\
\hline 4. To be aware how to incorporate spirituality in group process & 54.5 & 4 & $2.5-4$ \\
\hline 5. To be aware how to infuse spirituality in community process & 54.5 & 4 & $2.5-4$ \\
\hline $\begin{array}{l}\text { 6. To consider spirituality as a vehicle to occupational therapy } \\
\text { intervention }\end{array}$ & 45.5 & 4 & $3-4$ \\
\hline $\begin{array}{l}\text { 7. To consider clients' involvement during intervention so that clients } \\
\text { may share thelr spirituality with them }\end{array}$ & 63.6 & 4 & $3.5-4$ \\
\hline 8. To be aware how spirituality relates to individual personal journey & 81.8 & 4 & $4-4$ \\
\hline 9. To know how spirituality relates to enablers & 72.7 & 4 & $4-4$ \\
\hline 10. To be aware how spirituality relates to occupational performance & 81.8 & 4 & $4-4$ \\
\hline 11. To learn to acknowledge dients' prioritles related to spirituality & 81.8 & 4 & $4-4$ \\
\hline $\begin{array}{l}\text { 12. To learn to use clients' occupational cholces in order to motivate } \\
\text { clients' engagement in occupation }\end{array}$ & 81.8 & 4 & $4-4$ \\
\hline 13. To learn to differentlate spirituality and how it links with activitles & 72.7 & 4 & $4-4$ \\
\hline $\begin{array}{l}\text { 14. To find out from the clients the importance of prayer, meditation, } \\
\text { and sllent time }\end{array}$ & 45.5 & 3.5 & $1.75-4$ \\
\hline 15. To be aware of clients' rituals as part of spirituality & 72.7 & 4 & $4-4$ \\
\hline $\begin{array}{l}\text { 16. To be exposed to fieldwork visits to help students to observe and } \\
\text { learn about spirituality and spiritual care in practice }\end{array}$ & 63.6 & 4 & $3.5-4$ \\
\hline $\begin{array}{l}\text { 17. To be allowed to shadow in order to observe how other members } \\
\text { of the health team promote spirituality in practice }\end{array}$ & 72.7 & 4 & $4-4$ \\
\hline $\begin{array}{l}\text { 18. To be aware of the role of the Interdisciplinary panels in sharing } \\
\text { knowledge and Imparting skills about spirituality and spiritual care }\end{array}$ & 63.6 & 4 & $3.5-4$ \\
\hline
\end{tabular}

There was consensus among the panel participants regarding the knowledge-base that might inform the integration of spirituality and spiritual care into occupational therapy education. In Table 1, the majority of the panel participants (90.9\%) reached an agreement that understanding of spirituality and spiritual diversity in occupational therapy education is very important. Nine of the 11 panel participants (81.8\%) agreed that spiritual well-being, spiritual needs, and addressing fear of spirituality in teaching and learning are significant in occupational therapy education. About $72.7 \%(\mathrm{n}=8)$ panel participants agreed that spirituality is very important because it improves clients' quality of life. Therefore, the panel participants agreed that spirituality should be part of occupational therapy education from first year level. Two thirds of the panel participants (63.6\%) agreed that knowledge related to spiritual care, theory of meaning of occupational engagement, and spirituality might enhance occupational therapy understanding of human beings. Overall, the items related to the knowledge-base for spirituality and spiritual care gained highest agreement with median values ranging from 3.5 to 4 .

An importance of spirituality and spiritual care seems to resonate with the core foundation of occupational therapy education. Most panel participants (81.8\%) agreed that spirituality plays an important role in one's individual 
Table 3. Skllls required for spirituality and spiritual care.

\begin{tabular}{|c|c|c|c|}
\hline & $\begin{array}{c}\text { Consensus } \\
(\%)\end{array}$ & Medlan & $\begin{array}{l}\text { Interquartlle } \\
\text { range }\end{array}$ \\
\hline $\begin{array}{l}\text { 1. To be supported to enhance their skills such as a comprehenslve } \\
\text { history, spintual assessment and physical exam }\end{array}$ & 63.6 & 4 & $4-4$ \\
\hline 2. To be taught how to conduct spiritual assessment with clients & 45.5 & 4 & $3-4$ \\
\hline 3. To be provided a lesson on how to be sensittive & 72.7 & 4 & $4-4$ \\
\hline 4. To be taught how to be ethical about issues related to spirituality & 90.9 & 4 & $4-4$ \\
\hline 5. To be provided with possible questions to assess spiritual needs & 72.7 & 4 & $4-4$ \\
\hline $\begin{array}{l}\text { 6. To leam to seek, discern and use information obtained from an } \\
\text { assessment of spintuality }\end{array}$ & 72.7 & 4 & $4-4$ \\
\hline $\begin{array}{l}\text { 7. To be aware of how to assess spirituality according to age and } \\
\text { stage }\end{array}$ & 63.6 & 4 & $3-4$ \\
\hline $\begin{array}{l}\text { 8. To be guided about how to assess spirituality by providing them } \\
\text { with assessment tools }\end{array}$ & 54.5 & 4 & $3-4$ \\
\hline 9. To point out exactly where spirituality fits in occupational therapy & 63.6 & 4 & $2.75-4$ \\
\hline $\begin{array}{l}\text { 10. To address the relationship between spirituality and cultural } \\
\text { context }\end{array}$ & 90.9 & 4 & $4-4$ \\
\hline $\begin{array}{l}\text { 11. To be equipped with skills to address cllents' spiritual needs and } \\
\text { how to refer to relevant members }\end{array}$ & 54.5 & 4 & $4-4$ \\
\hline $\begin{array}{l}\text { 12. To develop and maintain a practice of good self-care in order to } \\
\text { attend to their own physical, emotional and spiritual well-being }\end{array}$ & 72.7 & 4 & $4-4$ \\
\hline 13. To know how to compensate for their health & 54.5 & 4 & $4-4$ \\
\hline $\begin{array}{l}\text { 14. To be provided with evidence to show how spirituality is } \\
\text { implemented in the real world }\end{array}$ & 63.6 & 4 & $4-4$ \\
\hline $\begin{array}{l}\text { 15. To be aware of the effectiveness of spirituality in occupational } \\
\text { therapy }\end{array}$ & 63.6 & 4 & $35-4$ \\
\hline $\begin{array}{l}\text { 16. To conduct evidence based research to help them understand how } \\
\text { spirituality is included in occupational therapy }\end{array}$ & 72.7 & 4 & $4-4$ \\
\hline $\begin{array}{l}\text { 17. To be able to learn how to demonstrate spiritual assessment skills, } \\
\text { assessment of spiritual needs, self-knowledge when addressing } \\
\text { spiritual needs, appropriate times and methods for making } \\
\text { appropriate referrals for spiritual care }\end{array}$ & 54.5 & 4 & $3-4$ \\
\hline $\begin{array}{l}\text { 18. To know how active listening forms part of spiritual care } \\
\text { intervention }\end{array}$ & 81.8 & 4 & $4-4$ \\
\hline $\begin{array}{l}\text { 19. To know the practical notions of patients' management according } \\
\text { to the integrative bio-psycho-socio-spiritual Integrative model }\end{array}$ & 54.5 & 4 & $4-4$ \\
\hline $\begin{array}{l}\text { 20. Students need to have an understanding of the most common } \\
\text { religlons, in order to take an accurate spiritual history }\end{array}$ & 63.6 & 4 & $275-4$ \\
\hline $\begin{array}{l}\text { 21. To be aware of the spiritual questions that can be expected with } \\
\text { patients related to their illness }\end{array}$ & 72.7 & 4 & $4-4$ \\
\hline $\begin{array}{l}\text { 22. To have a thorough knowledge of whole person-centered approach } \\
\text { In relation to understanding the human being as a spiritual being } \\
\text { with mind, body, and spirit }\end{array}$ & 81.8 & 4 & $4-4$ \\
\hline $\begin{array}{l}\text { 23. To be able to assess patients' body, mind and spiritual needs } \\
\text { of cllents }\end{array}$ & 81.8 & 4 & $4-4$ \\
\hline $\begin{array}{l}\text { 24. To be able to provide holistic care based on knowledge of } \\
\text { physiological, psychosocial, cultural, spiritual, and environmental } \\
\text { dimensions. }\end{array}$ & 81.8 & 4 & $4-4$ \\
\hline $\begin{array}{l}\text { 25. To be educated about the slgnificance of viewing human beings as } \\
\text { wholes rather than as sums of their parts }\end{array}$ & 90.9 & 4 & $4-4$ \\
\hline
\end{tabular}

journey, priorities, and occupational choices. The items gained the highest agreement with a median score of 4 within interquartile range between 25th quartile of 4 and $75^{\text {th }}$ quartile of 4. About $72.7 \%(n=8)$ panel participants agreed that spirituality relates to enablers, client's rituals, well-being, and health. Therefore, about one third of the panel participants (63.6\%) 
Table 4. Spirituality and spiritual care as related to ethics.

\begin{tabular}{|c|c|c|c|}
\hline & $\begin{array}{c}\text { Consensus } \\
(\%)\end{array}$ & Median & $\begin{array}{l}\text { Interquartile } \\
\text { range }\end{array}$ \\
\hline $\begin{array}{l}\text { 1. To introduce spirituality during an ethics course so that students } \\
\text { will have an understanding of how to address it with clients }\end{array}$ & 63.6 & 4 & $3-4$ \\
\hline $\begin{array}{l}\text { 2. Students should learn to identify ethical and boundary issues as } \\
\text { well as to provide privacy for clients' and families' need for solitude }\end{array}$ & 81.8 & 4 & $4-4$ \\
\hline $\begin{array}{l}\text { 3. To learn how to behave in an ethical manner without infringing } \\
\text { clients' rights and promote quality of life by adhering to a } \\
\text { person-centered approach }\end{array}$ & 72.7 & 4 & $3.75-4$ \\
\hline $\begin{array}{l}\text { 4. To be introduced to ethics while learning about spirituality and } \\
\text { spiritual care }\end{array}$ & 72.7 & 4 & $3.75-4$ \\
\hline $\begin{array}{l}\text { 5. To learn to respect patients' views and opinions to enhance their } \\
\text { communication }\end{array}$ & 72.7 & 4 & $3.75-4$ \\
\hline $\begin{array}{l}\text { 6. To learn to respect people's right to participate in their own health } \\
\text { care }\end{array}$ & 81.8 & 4 & $4-4$ \\
\hline $\begin{array}{l}\text { 7. To learn to recognize ethical, spiritual, and legal dimensions of } \\
\text { occupational therapy practice }\end{array}$ & 81.8 & 4 & $4-4$ \\
\hline
\end{tabular}

agreed it is important that occupational therapy students gain understanding of spirituality in different fieldwork placements so that they may learn about the role of interdisciplinary panels. These items gained agreement with a median value greater than 3.25 as presented in Table 2.

In occupational therapy education, it is imperative that students acquire skills related to spirituality and spiritual care. Almost all panel participants (90.8\%) agreed that students need to gain skills on how to view human beings as wholes rather than as sums of their parts. This finding resonates with the agreement of most of the panel participants (81.8\%) who agreed with the knowledge of a holistic person-centered approach as part of spiritual being with mind, body, and spirit. As a result, the panel participants agreed that students should learn how to assess patients' body, mind, and spiritual needs. Table 3 presents the items related to the skills for spirituality and spiritual care with a highest median score of 4 . Panel participants (81.8\%) reached the highest agreement that "students should know how to use active listening as a spiritual care intervention" with a median value of 4 . Almost all of the panel participants (90.9\%) agreed that there is a relationship between spirituality and cultural context as presented in Table 3 .

In relation to the skills for spirituality and spiritual care, almost all panel participants (90.9\%) agreed that students need to gain and apply ethical

Table 5. Pedagogical approaches for spirituality and spiritual care.

\begin{tabular}{|c|c|c|c|}
\hline Transformational learning in spirituality and spiritual care & $\begin{array}{c}\text { Consensus } \\
(\%)\end{array}$ & Median & $\begin{array}{c}\text { Interquartile } \\
\text { range }\end{array}$ \\
\hline $\begin{array}{l}\text { 1. To be challenged about their belief systems as they will be working } \\
\text { with clients who are different from them }\end{array}$ & 54.5 & 4 & $2.5-4$ \\
\hline 2. To engage in dialogues about their understanding of spirituality & 63.6 & 4 & $3.5-4$ \\
\hline 3. To be aware of what makes a person a spiritual being & 72.7 & 4 & $3.75-4$ \\
\hline
\end{tabular}


Table 6. Teaching strategles for spirituality and spiritual care.

\begin{tabular}{|c|c|c|c|}
\hline & $\begin{array}{c}\text { Consensus } \\
\text { [56) }\end{array}$ & Medlan & $\begin{array}{l}\text { Interquartlle } \\
\text { range }\end{array}$ \\
\hline 1. To expose students to spirituality using experlentlal learning & 54.5 & 4 & $3-4$ \\
\hline $\begin{array}{l}\text { 2. To be given an opportunily to experience spirttuality within } \\
\text { occupatlonal therapy modules }\end{array}$ & 54.5 & 4 & $3-4$ \\
\hline $\begin{array}{l}\text { 3. To be allowed to engage in role plays about spirtiuality that mimic } \\
\text { the real worid }\end{array}$ & 54.5 & 4 & $3-4$ \\
\hline $\begin{array}{l}\text { 4. To learn to observe during the role play in order to enhance their } \\
\text { problem solving, critical reflection and communication skills }\end{array}$ & 63.6 & 4 & $3.5-4$ \\
\hline 5. To leam to share their own perspectlves about spirtuality & 72.7 & 4 & $3.75-4$ \\
\hline 6. To be exposed to spirttuallty and culture through experlence & 81.8 & 4 & $4-4$ \\
\hline $\begin{array}{l}\text { 7. To leam to make sense of their learning experiences regarding } \\
\text { spirituality }\end{array}$ & 72.7 & 4 & $3.75-4$ \\
\hline $\begin{array}{l}\text { 8. To leam about spirituality and spirttual care through the use of } \\
\text { role-plays to allow them to share their understandling }\end{array}$ & 54.5 & 4 & $3-4$ \\
\hline 9. To be given an opportunily to reflect about spirituality & 90.9 & 4 & $4-4$ \\
\hline 10. To be given an exposure to dlscuss what they have experlenced & 54.5 & 4 & $4-4$ \\
\hline $\begin{array}{l}\text { 11. To be allowed to use the Kolb's experlentlal learning cycle in order } \\
\text { to reflect about spirtualty from a personal view }\end{array}$ & 45.5 & 4 & $3-4$ \\
\hline 12. To allow students to refect from the level of spirtual being & 45.5 & 4 & $2.25-4$ \\
\hline 13. To allow students to refect from an occupational belng & 36.4 & 3.50 & $25-4$ \\
\hline 14. To learn to use joumals as a platform for spiritualty & 45.5 & 4 & $3-4$ \\
\hline $\begin{array}{l}\text { 15. To learn to write journals about Indlviduals' spiritual Journeys this } \\
\text { would help them to have an understanding of themselves and } \\
\text { others }\end{array}$ & 45.5 & 3.50 & $275-4$ \\
\hline 16. To learn to self-reflect in order to share their spirtuallity & 54.5 & 4 & $3-4$ \\
\hline 17. To learn to define spirtuallty from their personal perspective & 63.6 & 4 & $3-4$ \\
\hline 18. To leam to identify elements of spirituality & 63.6 & 4 & $3-4$ \\
\hline $\begin{array}{l}\text { 19. To be exposed to experientlal and reflectlve journaling to provide a } \\
\text { platfom to express thelr views about the experiences of spirtuality } \\
\text { in cilnical practlce and education }\end{array}$ & 45.5 & 3.50 & $3-4$ \\
\hline 20. To create awareness for proper understanding of spirtuallty & 54.5 & 4 & $3-4$ \\
\hline 21. To be allowed to have interactive day to share about spirtuallty & 54.5 & 4 & $3-4$ \\
\hline 22. To be allowed to have a spirltual and cultural day & 63.6 & 4 & $3-4$ \\
\hline $\begin{array}{l}\text { 23. To be allowed to share their spirituality in Academic Research } \\
\text { Cinical }\end{array}$ & 45.5 & 3.50 & $3-4$ \\
\hline 24. To be given a topic about spirtuality and cuture & 54.5 & 4 & $3-4$ \\
\hline $\begin{array}{l}\text { 25. To engage in debates about spirituality, religion and culture in } \\
\text { order to faciltate their critical reasoning }\end{array}$ & 54.5 & 4 & $3-4$ \\
\hline 26. To brainstom about spintuality to get others' vews & 63.6 & 4 & $3-4$ \\
\hline $\begin{array}{l}\text { 27. Students need to engage In dlalogue about spirttualty and spirtual } \\
\text { care during dass so that they may ralse their awareness about the } \\
\text { two concepts in relation to health }\end{array}$ & 72.7 & 4 & $3-4$ \\
\hline $\begin{array}{l}\text { 28. To Invite guest lecturers to share spirtuality information with } \\
\text { students }\end{array}$ & 54.5 & 4 & $3-4$ \\
\hline $\begin{array}{l}\text { 29. Guest speakers should be Invited to share their knowledge about } \\
\text { spirituality with students and educators as collaborators }\end{array}$ & 63.6 & 4 & $3-4$ \\
\hline 30. To be taught in class about spirtuality through classroom lectures & 54.5 & 4 & $3-4$ \\
\hline $\begin{array}{l}\text { 31. To leam from educators as role-models how to balance professlonal } \\
\text { boundarles and personal lives and encouraging students to have } \\
\text { openness, respect, tolerance and the courage to handle existentlal } \\
\text { paln }\end{array}$ & 54.5 & 4 & $3-4$ \\
\hline $\begin{array}{l}\text { 32. To be given an opportunily to work in groups to prepare } \\
\text { presentations about spiritualty }\end{array}$ & 54.5 & 4 & $3-4$ \\
\hline \multirow{2}{*}{$\begin{array}{l}\text { 33. To be invoived in group dlscussions about spiritualty and spirttual } \\
\text { care }\end{array}$} & 63.6 & 4 & $3-4$ \\
\hline & 72.7 & 4 & $3-4$ \\
\hline
\end{tabular}


Table 6. Continued.

\begin{tabular}{|c|c|c|c|}
\hline & $\begin{array}{c}\text { Consensus } \\
(\%)\end{array}$ & Median & $\begin{array}{l}\text { Interquartlle } \\
\text { range }\end{array}$ \\
\hline \multicolumn{4}{|l|}{$\begin{array}{l}\text { 34. To be exposed to small groups in class to express their vlews and } \\
\text { misconceptions about spirituality in a supported and trusting } \\
\text { relationship with educators and other students }\end{array}$} \\
\hline $\begin{array}{l}\text { 35. To be in an environment that promotes sharing about spirituality as } \\
\text { It relates to diversity, connections with others, nature and self }\end{array}$ & 72.7 & 4 & $3-4$ \\
\hline $\begin{array}{l}\text { 36. To be in an environment conducive to allowing reflection, group } \\
\text { discussions and journal writing to promote learning }\end{array}$ & 54.5 & 4 & $3-4$ \\
\hline $\begin{array}{l}\text { 37. To work in groups then use a case study to facilitate thelr } \\
\text { understanding of spirituality in order to enhance thelr problem } \\
\text { solving, critical thinking and collaboration }\end{array}$ & 54.5 & 4 & $3-4$ \\
\hline $\begin{array}{l}\text { 38. Students' self-awareness should be Increased to enable thelr } \\
\text { personal spiritual development }\end{array}$ & 63.6 & 4 & $3-4$ \\
\hline $\begin{array}{l}\text { 39. To be enabled to Improve their self-reflection skllls and knowing } \\
\text { themselves more deeply }\end{array}$ & 72.7 & 4 & $3.75-4$ \\
\hline 40. To develop thelr own values and spirituality & 72.7 & 4 & $3-4$ \\
\hline $\begin{array}{l}\text { 41. To be able to analyze thelr own and others' spiritual status in three } \\
\text { dimensions of a relationship - with themselves, others, and with } \\
\text { respect to falth, to enhance their spiritual assessment skills }\end{array}$ & 63.6 & 4 & $3-4$ \\
\hline $\begin{array}{l}\text { 42. To be allowed to have awareness and self-discovery to enable them } \\
\text { to sharpen thelr critical thinking skills about thelr own spirituality, } \\
\text { education and practice }\end{array}$ & 54.5 & 4 & $3-4$ \\
\hline $\begin{array}{l}\text { 43. To learn to use internet, online pedagogy and online tutorlals to } \\
\text { learn about spirituality and spiritual care }\end{array}$ & 45.5 & 3.5 & $2.75-4$ \\
\hline 44. To be exposed to online tutorials about spirituality & 45.5 & 3.5 & $2.75-4$ \\
\hline
\end{tabular}

reasoning skills on issues related to spirituality. Most of the panel participants (81.8\%) agreed that respect for people's right to participate in health care needs to be part of occupational therapy education. Additionally, the panel participants (81.8\%) agreed that recognition of ethical, spiritual, and legal dimensions in occupational therapy enhance service delivery. The item related to introduction of spirituality during an ethics courses gained support from two thirds of the panel participants (63.6\%). This item resonates with the highest agreement from about $72.7 \%(n=8)$ panel participants, who agreed that students need to behave in an ethical manner without infringing clients' rights and promote quality of life by adhering to a person-centered approach, with a median value of 4 as depicted in Table 4 .

Table 7. Assessment strategies for learning about spirituality and spiritual care.

\begin{tabular}{lccc}
\hline & $\begin{array}{c}\text { Consensus } \\
(\%)\end{array}$ & \multicolumn{2}{c}{$\begin{array}{c}\text { Interquartile } \\
\text { range }\end{array}$} \\
\hline $\begin{array}{l}\text { 1. To be assessed about spirituality and spiritual care by means of } \\
\text { reflective journals, post-clinical conferences, knowledge of }\end{array}$ & 54.5 & 4 & $3-4$ \\
$\quad$ literature, and session evaluations & & & \\
2. To assess students' understanding of spirituality and religion & 63.6 & 4 & $3-4$ \\
$\begin{array}{l}\text { 3. To assess students' knowledge and understanding of spirituality } \\
\quad \text { using assignment }\end{array}$ & 54.5 & 4 & $3-4$ \\
$\begin{array}{l}\text { 4. Students' knowledge about spirituality and spiritual care should be } \\
\text { assessed by means of self-report, written examination, written and } \\
\text { oral presentations, standardized patient case studies, and clinical } \\
\text { evaluations }\end{array}$ & 54.5 & 4 & $2-4$ \\
\hline
\end{tabular}


There is a need for pedagogical approaches for spirituality and spiritual care in occupational therapy education as presented in Table 5. About $72.7 \%(\mathrm{n}=8)$ panel participants agreed that students need to be aware of what makes a person a spiritual being. Therefore, two thirds of the panel participants (63.6\%) agreed that engaging in dialogues about understanding of spirituality might enhance students' knowledge. However, slightly more than half of the panel participants (53.5\%) agreed that students need to be challenged so that they might engage in the dialogues about belief systems in preparation for them to work with clients from different backgrounds. Overall, these items gained highest agreement with a median value of 4 .

The panel participants agreed on a range of teaching and learning strategies that might be used for spirituality and spiritual care as presented in Table 6. Almost all panel participants (90.9\%) were in favor of giving students an opportunity to reflect about spirituality. Hence, about $72.7 \%(\mathrm{n}=8)$ panel participants agreed that self-reflection skills need to be part of occupational therapy education so that student might know themselves more deeply. Panel participants agreed that teaching and learning strategies such as experiential learning, role plays, writing journals, debates, guest lecturers, group discussions, case study, self-discovery, and online pedagogy and tutorials. These strategies gained highest median values ranging from 3.5 to 4 .

Panel participants agreed that occupational therapy education needs to consider how to assess students understanding of spirituality and spiritual care. About two thirds of panel participants (63.6\%) agreed it is important that students get assessed on their understanding of spirituality and religion. Therefore, slightly more than half of the panel participants (54.5\%) agreed that reflective journals, assignments, case studies, clinical evaluations, and written and oral presentations could be used as assessment strategies as presented in Table 7 with median values ranging from 2 to 4 .

\section{Discussion}

The purpose of this modified Delphi study was to design and develop guidelines to integrate spirituality and spiritual care into occupational therapy education. Overall, a total of 126 items gained highest agreements based on the consensus, median values, and interquartile ranges (Tables 1-7). The median values ranging from 2 to 4 shows how the panel participants agreed about the educational guidelines recommended in this study. These guidelines can be viewed as an initial support for occupational therapy educators and students when planning to integrate spirituality and spiritual care into occupational therapy education.

The findings of the current modified Delphi study highlighted that the educational guidelines need to incorporate content knowledge-base for spiritual well-being, spiritual coping, spiritual distress, and spiritual needs. In agreement with the literature, the educational guidelines recommend that spirituality, spiritual care, and religion need to be integrated into occupational therapy education from first- to fourth-year levels. These educational guidelines corroborate with Caldeira and colleagues (2016), who suggested that spirituality and 
spiritual care should be included in the curriculum in order to promote holistic care. Additionally, these guidelines conform to previous studies, which suggested that students in social work and medicine should examine religion and spirituality as an important aspect of human culture and existence (Bhagwan, 2002; Janse van Rensburg, 2014). In relation to the understanding of religion and spirituality, however, the educational guidelines recommend that spiritual diversity need to be part of occupational therapy education. A possible explanation for this guideline might be that the panel participants agreed on spiritual diversity because occupational therapy education appeared to promote an integrated approach to address spirituality and spiritual care. The integrated approach consists of moral and faith development-related issues, bio-psycho-social-spiritual journeys, and critical view of individuals. The educational guidelines recommend that a theory of meaning of occupational engagement and spirituality need to be part of occupational therapy education. This recommendation is consistent with previous studies, which indicated that there is a relationship between spirituality and occupational engagement (Mthembu et al., 2017b; Wilding, 2007; Wilding, May, \& Muir-Cochrane, 2005).

There were highest median values for agreements on the educational guidelines related to priorities, occupational performance, and occupational choices, resonating with Wilding and colleagues' (2005) and Caldeira and colleagues' (2016) idea that spirituality forms the foundation of meaningful doing, coping, and managing chronic illnesses like mental illness. The educational guideline recommends that occupational therapy students need to know that spirituality improves well-being and health of the client. This guideline is in agreement with Wilding and colleagues' (2005) findings, which showed that spirituality is a phenomenon that acts as life sustaining. The current study highlights that an educational guideline related to the importance of clients' ritual as part of spirituality is crucial for occupational therapy education. This guideline accords with the Occupational Therapy Framework, which supported that clients' ritual forms an important aspect of performance patterns, which enables engagement in occupations or activities (American Occupational Therapy Association [AOTA], 2014). AOTA's (2014) assertion corroborates the guideline from the current study, which recommends spirituality relates to enablers of occupation. This guideline highlights that occupational therapy education needs to assist students with more knowledge about spirituality as an enabler. The results corroborate with Mthembu and colleagues (2017b), Wilding (2007), as well as Johnston and Mayers (2005), who noted that spirituality seemed to be a driving force that motivates people to engage in their occupations. This suggests that occupational therapy educators could assist students to understand the significance of spirituality and how it relates to occupations. Additionally, this finding could be supported by the results of the study that reached consensus on the item "students should be aware of importance of spirituality in different fieldwork placements" (Table 2). This is supported by previous studies, which indicated spirituality plays an important role in therapy with individuals, families, groups, as well as in mental health and community (Hess \& Ramugondo, 2014; Janse van Rensburg, 2014; Mthembu et al., 2017b).

In this study, the highest median values indicated that students need to acquire skills related to spirituality and spiritual care in occupational therapy as illustrated in Table 3. The panel 
participants agreed that the educational guidelines need to ensure students learn skills such as comprehensive history taking, assessment of spiritual needs, physical exam, active listening, sensitivity, age and stage, evidence-based research, self-care management, and ethical reasoning. The educational guidelines reflect previous studies, which indicated students should be assisted to improve their assessment of the patient across the life span and develop clinical reasoning regarding spirituality (Caldeira et al., 2016; Janse van Rensburg, 2014; Moreira-Almeida, Koenig, \& Lucchetti, 2014; Mthembu et al., 2016; Tanyi, 2006). The educational guidelines of this study showed active listening is a skill that students need to have in order to provide spiritual care. These educational guidelines further support the accentuation of AOTA (2014), which recommends the importance of therapeutic use of self to facilitate open communication and connection with clients. As a result, the students might be able to "develop a collaborative relationship with clients in order to understand their experiences and wishes for intervention" (AOTA, 2014, p. S12).

The educational guidelines scored highest median values from the present study, and previous studies indicated that ethics appears to be one of the crucial areas where spirituality and spiritual care might be integrated in health sciences education including occupational therapy education (Becker, 2009; Bhagwan, 2002; Hess \& Ramugondo, 2014; Tanyi, 2006). The results of this study indicate that spirituality and spiritual care may be incorporated in studies of ethics. Hence, the consensus among the panel participants highlighted the view that students may learn to recognize ethical, spiritual, and legal dimensions of occupational therapy practice. This may contribute to the body of knowledge in occupational therapy education regarding spirituality, spiritual care, and ethics. Additionally, this is in agreement with the findings of Caldeira and colleagues (2016), who reported that the curricular units for inclusion of spirituality may include professional ethics. Freire and Moleiro (2015) and Janse van Rensburg (2014) highlighted the importance of ethical considerations to promote respect and non-discrimination, and should be part of collaboration with a religious adviser.

There are concerns about pedagogical approaches for teaching spirituality and spiritual care to health professionals (Baldacchino, 2015; Becker, 2009; Bennett \& Thompson, 2015; Caldeira et al., 2016; Cruz, Alshammari, Alotaibi, \& Colet, 2017); however, the modified Delphi study identified transformational learning as a useful imperative approach. For example, in discussing the importance of transformational learning, panel participants agreed that students should engage in dialogue about their understanding of spirituality as it incorporates cognitive and affective learning. It is difficult to explain this result, but it may have something to do with the highest agreement in the item "students should be aware what makes a person a spiritual being" that received the highest mean value. A possible explanation for this, however, is that "students should be able to provide holistic care based on knowledge of physiological, psychosocial, cultural, spiritual, and environmental dimensions" (Table 3). This educational guideline could be explained by the results of Bhagwan (2002), who reported that students need to be aware of their own spiritual and religious beliefs, practices, and experiences, as well as how it may influence their work with clients. Bennett and Thompson's (2015) systematic review added that students may need to have information about both spirituality and good communication skills. 
It was noteworthy that the panel participants reached highest agreement about a variety of teaching and learning strategies for spirituality and spiritual care as well as their relevance in occupational therapy education. For example, in discussing the various teaching and learning strategies, the participants agreed that these strategies should include experiential learning, role plays, journals, debates, dialogue, guest lecturers, group discussions, and case studies. In addition, self-reflection was considered a learning strategy to foster students' self-awareness regarding spirituality. In addition, self-reflection was considered as one of the important strategies in the educational guidelines. The teaching and learning strategies identified in the current study are consistent with those of previous studies that acknowledged drama, role playing, case study and discussion, searching databases and research analysis, self-reflection exercises, journaling, tutorial supervision, oral presentation about spirituality, group dynamics, and film and text analysis (Baldacchino, 2015; Bennett \& Thompson, 2015; Caldeira et al., 2016; Mthembu et al., 2016). Additionally, Baldacchino (2015) described conceptual models, which may enhance learning about spirituality and spiritual care, such as Kolb's (1984) experiential learning theory, Gibbs' (1988) theory of reflective learning, and the ASSET model for Actioning Spirituality and Spiritual Care Education and Training in nursing (Narayanasamy, 1999). These models recommend possible actions that educators may use to integrate spirituality into health sciences education including occupational therapy.

The educational guidelines from the current study highlight the importance of assessing students' knowledge and understanding of spirituality and spiritual care in occupational therapy education. Previous studies reported that assessment of students' learning about spirituality and spiritual care seemed to be lacking in occupational therapy education (Mthembu et al., 2017a). In contrast to earlier findings, however, the highest agreements in the present study provide evidence of assessment strategies that may be useful to assess students' understanding of and insight into spirituality and spiritual care. The educational guidelines recommended assessment strategies that occupational therapy educators need to use. These assessment strategies included: (1) portfolio of evidence, (2) assignment, (3) questionnaire, and (4) observational standardized practical evaluation. These results are consistent with those of Bennett and Thompson (2015), who suggested that elements of spirituality could be incorporated in assignments where students practice spiritual assessment in a safe and conducive environment.

To our knowledge, this is the first use and reporting of a modified Delphi study to develop educational guidelines for integrating spirituality and spiritual care into occupational therapy education. Therefore, there are several limitations that must be kept in mind when considering the results of the modified Delphi study. First, only female participants responded and returned their responses, and none of the male experts responded to the invitation to be part of the study. Their participation would have provided insight into men's understanding of, and consensus regarding, spirituality and spiritual care in occupational therapy education. Second, by its nature, a Delphi study tends to be time consuming for participants, which might have influenced the participation. 
The hope is that this study will substantially provide occupational therapy educators and students with clear educational guidelines to integrate spirituality and spiritual care into educational programs. Therefore, the educational guidelines may also serve as the first step to inform transformation of occupational therapy curriculum to consider spirituality. Additionally, the guidelines can inform the process of actioning the development of a position statement regarding spirituality in occupational therapy in the South African context. In addition, the content and scope of the educational guidelines developed in this study have to be disseminated, implemented, and evaluated to other institutions of higher learning to assess the applicability and be reviewed.

\section{Conclusion}

The purpose of this study was to provide educational guidelines that would inform the integration of spirituality and spiritual care into occupational therapy education in order to promote integrative education and holistic care. The educational guidelines highlighted the content knowledge-base of spirituality, spiritual care, spiritual well-being, spiritual diversity, and spiritual needs. The current educational guidelines have gone some way toward providing teaching and learning strategies related to the transformational learning pedagogical approach. This study will serve as a base for future studies and occupational therapy programs that seem to struggle with preparing occupational therapy graduates to be spiritually sensitive. Furthermore, the guidelines may help to promote better understanding of the diversity of spiritual beliefs, and practices related to spirituality and religion among individuals, groups, and communities in South Africa. Further research needs to be completed to evaluate the effectiveness of the educational guidelines.

\section{Acknowledgements}

The authors would like to thank the University of the Western Cape for granting permission to conduct the study. We are grateful for all the participants for their participation in the study.

\section{Declaration of conflicting interests}

Any opinion, finding, and conclusion or recommendation expressed in this material is that of the author(s), and the National Research Foundation (NRF) does not accept any liability in this regard.

\section{Funding}

This work is based on the research supported in part by the NRF of South Africa for the grant, Unique Grant No. 93992.

\section{References}

American Occupational Therapy Association (AOTA). (2014). Occupational therapy practice framework: Domain and process (3rd ed.). American Journal of Occupational Therapy, 68(Suppl. 1), S1-S48. doi:10.5014/ajot.2014.68200

Armstrong, J. S. (2001). Principles of forecasting: A handbook for researchers and 
practitioners. New York, NY: Springer Science +Business Media, LLC.

Avella, J. R. (2016). Delphi panels: Research design, procedure, advantages, and challenges.

International Journal of Doctoral Studies, 11, 305-321. doi:10.1002/pts.2221

Baldacchino, D. (2015). Spiritual care education of health care professionals. Religions, 6, 594-613. doi:10.3390/rel6020594

Becker, A. (2009). Ethical considerations of teaching spirituality in the academy. Nursing Ethics, 16(6), 697-706. doi:10.1177/0969733009342639

Bennett, V., \& Thompson, M. I. (2015). Teaching spirituality to student nurses. Journal of Nursing Education and Practice, 5(2), 26-33.

Bhagwan, R. (2002). The role of religion and spirituality in social work practice: Guidelines for curricula development at South African schools of social work (PhD Thesis). University of KwaZulu-Natal, Durban, South Africa.

Boulkedid, R., Abdoul, H., Loustau, M., Sibony, O., \& Albert, C. (2011). Using and reporting the Delphi method for selecting healthcare quality indicators: A systematic review. PLoS ONE, 6(6), 1-9. doi:10.1371/journal.pone.0020476

Brémault-Phillips, S., Olson, J., Brett-Maclean, P., Oneschuk, D., Sinclair, S., Magnus, R., ... Puchalski, C. M. (2015). Integrating spirituality as a key component of patient care. Religions, 6, 476-498. doi:10.3390/rel6020476

Caldeira, S., Figueiredo, A. S., da Conceição, A. P., Ermel, C., Mendes, J., Chaves, E., ... Vieira, M. (2016). Spirituality in the undergraduate curriculum of nursing schools in Portugal and São Paulo-Brazil. Religions, 7, 134. doi:10.3390/rel7110134

Cruz, J. P., Alshammari, F., Alotaibi, K. A., \& Colet, P. C. (2017). Spirituality and spiritual care perspectives among baccalaureat nursing students in Saudi Arabia. Nurse Education Today, 49, 156-162. doi:10.1016/j.nedt.2016.11.027

Custer, R. L., Scarcella, J. A., \& Stewart, B. R. (1999). The modified Delphi technique-A rotational modification. Journal of Career and Technical Education, 15(2), 50-58. doi:10.21061/jcte.v14i2.702

Egan, M., \& Swedersky, J. (2003). Spirituality as experienced by occupational therapists in practice. American Journal of Occupational Therapy, 57, 525-533. doi:10.5014/ajot.57.5.525

Eubank, B. H., Mohtadi, N. G., Lafave, M. R., Wiley, P., Bois, A. J., Boorman, R. S., \& Sheps, D. M. (2016). Using the modified Delphi method to establish clinical consensus for the diagnosis and treatment of patients with rotator cuff pathology. BMC Medical Research Methodology, 16(56), 1-15. doi:10.1186/s12874-016-0165-8

Freire, J., \& Moleiro, C. (2015). Religiosity, spirituality, and mental health in Portugal: A call for a conceptualisation, relationship, and guidelines for integration (a theoretical review). Revista Psicologia, 29(2), 17-32. doi:10.17575/rpsicol.v29i2.1006

Garland, R. (1991). The mid-point on a rating scale: Is it desirable? Marketing Bulletin, 2, 66-70.

Gibbs, G. (1988). Learning by doing: A guide to teaching and learning methods. Oxford, England: Further Education Unit Oxford Polytechnic.

Green, K., Armstrong, J. S., \& Graefe, A. (2007). Methods to elicit forecasts from groups: Delphi and prediction markets compared. Foresight, 8, 17-20.

Hasson, F., Keeney, S., \& McKenna, H. (2000). Research guidelines for the Delphi survey 
technique. Journal of Advanced Nursing, 32, 1008-1015.

doi:10.1046/j.1365-2648.2000.to1-1-01567.x

Hemphill, B. (2015). Spiritual assessments in occupational therapy. The Open Journal of

Occupational Therapy, 3(3), 1-16. doi:10.15453/2168-6408.1159

Henriksen, R. C., Polonyi, M. A., Bornsheuer-Boswell, J. N., Greger, R. G., \& Watts, R. E.

(2015). Counseling students' perceptions of religious/spiritual counselling training: A qualitative study. Journal of Counseling \& Development, 93, 59-69. doi:10.1002/j.1556-6676.2015.00181.x

Hess, K. Y., \& Ramugondo, E. (2014). Clinical reasoning used by occupational therapists to determine the nature of spiritual occupations in relation to psychiatric pathology. British Journal of Occupational Therapy, 77(5), 234-242. doi:10.4276/030802214x13990455043449

Hoyland, M., \& Mayers, C. (2005). Is meeting spiritual need within the occupational therapy domain? British Journal of Occupational Therapy, 68(4), 177-180. doi:10.1177/030802260506800406

Hsu, C., \& Sandford, B. A. (2007). The Delphi technique: Making sense of consensus. Practical Assessment, Research \& Evaluation, 12(10), 1-8.

Janse van Rensburg, A. B. R. (2014). South African society of psychiatrists' guidelines for the integration of spirituality in the approach to psychiatric practice. South African Journal of Psychiatry, 20(4), 133-139. doi:107196/SAJP.593

Johnston, D., \& Mayers, C. (2005). Spirituality: A review of how occupational therapists acknowledge, assess and meet spiritual needs. British Journal of Occupational Therapy, 68(9), 386-392. doi:10.1177/030802260506800902

Jones, J. (2016). A qualitative study exploring how occupational therapists embed spirituality into their practice (Doctoral thesis). University of Huddersfield, Queensgate, Huddersfield, England.

Keenay, S., Hasson, F., \& Mckenna, H. (2006). Consulting the oracle: Ten lessons from using the Delphi technique in nursing research. Journal of Advance Nursing, 53(2), 205212. doi:10.1111/j.1365-2648.2006.03716.x

Khosrow-Pour, M. (2015). Encyclopedia of information science and technology (3rd ed.). Hershey, PA: Information Science Reference.

Kirsh, B., Dawson, D., Antolikova, S., \& Reynolds, L. (2001). Developing awareness of spirituality in occupational therapy students: Are our curricula up to the task? Occupational Therapy International, 8(2), 119-125. doi:10.1002/oti.138

Kolb, D. A. (1984). Experiential learning: Experience as the source of learning and development. Englewood Cliffs, NJ: Prentice Hall.

Moreira-Almeida, A., Koenig, H. G., \& Lucchetti, G. (2014). Clinical implications of spirituality to mental health: Review evidence and practical guidelines. Revista Brasileira de Psiquiatria, 36, 176-182. doi:10.1590/1516-4446-2013-1255

Moreira-Almeida, A., Sharma, A., Janse van Rensburg, B., Verhagen, P. J., \& Cook, C. C. H. (2016). World psychiatry association (WPA) position statement on spirituality and religion in psychiatry. World Psychiatry, 15(1), 87-88. doi:10.1002/wps.20304

Morris, D. N., Stecher, J., Briggs-Peppler, K. M., Chittenden, C. M., Rubira, J., \& Wismer, L. 
K. (2014). Spirituality in occupational therapy: Do we practice what we teach? Journal of Religion and Health, 53(1), 27-36. doi:10.1007/s10943-012-9584-y

Mthembu, T. G., Wegner, L., \& Roman, N. V. (2016). Teaching spirituality and spiritual care in health sciences education: A systematic review. African Journal for Physical Activity and Health Sciences, 22(41), 1036-1057.

Mthembu, T. G., Wegner, L., \& Roman, N. V. (2017a). Barriers to integration of spirituality and spiritual care in occupational therapy education in a South African context. Journal of Spirituality in Mental Health, 19(1), 61-79. doi:10.1080/19349637.2016.1206843

Mthembu, T. G., Wegner, L., \& Roman, N. V. (2017b). Exploring occupational therapy students' perceptions of spirituality in occupational therapy groups: A qualitative study. Occupational Therapy in Mental Health, 33(2), 1-27.

doi:10.1080/0164212X.2016.1245595

Narayanasamy, A. (1999). ASSET; A model for actioning spirituality and spiritual care education and training in nursing. Nurse Education Today, 19, 274-285. doi:10.1054/nedt.1999.0637

Polatjako, H. J., Townsend, E. A., \& Craik, J. (2007). The Canadian model of occupational performance and engagement. In E. A. Townsend \& H. J. Polatjako (Eds.), Enabling occupation II: Advancing an occupational therapy vision for health, well-being, \& justice through occupation (p. 23). Ottawa, ON: CAOT Publications ACE.

Puchalski, C. M. (2001). Spirituality and health: The art of compassionate medicine. Hospital Physician, 37, 30-36.

Puchalski, C. M., Vitillo, R., Hull, S. K., \& Reller, N. (2014). Improving the spiritual dimension of whole person care: Reaching national and international consensus. Journal of Palliative Medicine, 17(6), 642-656. doi:10.1089/jpm.2014.9427

Skulmoski, G. J., Hartman, F. T., \& Krahn, J. (2007). The Delphi method for graduate research. Journal of Information Technology Education, 6, 1-21.

Statistical Package for the Social Sciences (SPSS). (2016). SPSS 23 for windows. Chicago, IL:SPSS, Inc.

Sumsion, T., Tischler-Draper, L., \& Heinicke, S. (2011). Applying the Canadian model of occupational performance. In E. A. S. Duncan (Ed.), Foundations for practice in occupational therapy (5th ed., pp. 81-91). Edinburgh, Scotland: Churchill Livingston. Elsevier.

Tanyi, R. A. (2006). Spirituality and family nursing: Spirituality assessment and interventions for families. Journal of Advanced Nursing, 53(3), 287-294. doi:10.1111/j.1365-2648.2006.03731.x

Thompson, B. E., \& MacNeil, C. (2006). A phenomenological study exploring the meaning of a seminar on spirituality for occupational therapy students. The American Journal of Occupational Therapy, 60(5), 531-539. doi:10.5014/ajot.60.5.531

Wilding, C. (2007). Spirituality as substance for mental health and meaningful doing: A case illustration. The Medical Journal Australia, 186(10), 67.

Wilding, C., May, E., \& Muir-Cochrane, E. (2005). Experience of spirituality, mental illness and occupation: A life-sustaining phenomenon. Australian Occupational Therapy, 52, 2-9. doi:10.1111/j.1440-1630.2005.00462.x 
World Health Organization (WHO). (2015). World health organization definition of palliative care. Retrieved from http://www.who.int/cancer/palliative/definition/en/ 